Available online at website :

http:/ / e-journal.adpgmiindonesia.com/index.php/jmie

JMIE: Jurnal Pendidikan Madrasah Ibtidaiyah, 5(1), 2021, 30-45

\title{
PENGARUH MODEL PERMAINAN FINDING MY SECRET WORD TERHADAP KEMAMPUAN KOMUNIKASI MATEMATIS SISWA
}

\author{
Laila Farhanah 1), Fatkhul Arifin²)
}

Universitas Islam Negeri (UIN) Syarif Hidayatullah Jakarta

E-mail: lailafarhanah@gmail.ac.id ${ }^{1)}$,fatkhul_arf@uinjkt.ac.id ${ }^{2)}$

Submit: 16 Juli 2020, Revision: 31 Desember 2020, Approve: 19 Mei 2021

\begin{abstract}
The purpose of this study was to determine the effect of using the game finding my secret word on stdents mathematical communication ability. This research was conducted at SD Negeri Jampang 03 class V in the academic year 2019/2020. The research method used was quasi experiment with The Nonequivalent Posttest-Only Group Design. Sample this study amounted to 58 students consisting of 29 experimental class students and 29 control class students. The instrument used in this study was a matter of essay. The data obtained were analyzed by Independent Sample t-Test which produced Sig. ( 2 -tailed) of $0.005<0.05$, then $\mathrm{H} 0$ is rejected and $\mathrm{H} 1$ is accepted. This shows that the average value of students mathematical communication ability taught using the game finding my secret word is higher than the average value of students mathematical communication ability taught by conventional learning. Thus, the use of the game finding my secret word has a significant affects on student mathematical communication ability..
\end{abstract}

Keywords : Learning Model, Game Finding My Secret Word, Mathematical Communication Ability.

Pengutipan: Laila Farhanah \& Fatkhul Arifin . (2021). Pengaruh Model Permainan Finding My Secret Word Terhadap Kemampuan Komunikasi Matematis Siswa. JMIE: Journal of Madrasah Ibtidaiyah Education, 5(1), 2021, 30-45. jmie.v5i1.176.

Permalink/DOI: http:/ dx.doi.org/10.32934/jmie.v5i1.176 


\section{PENDAHULUAN}

Kemajuan suatu bangsa dan negara sangat ditentukan oleh pendidikan. Di Indonesia, pendidikan diatur dalam Undang-undang RI No. 20 Tahun 2003 tentang Sistem Pendidikan Nasional pada pasal 1 menyatakan bahwa, pendidikan adalah usaha sadar dan terencana untuk mewujudkan suasana belajar dan proses pembelajaran agar peserta didik secara aktif mengembangkan potensi dirinya untuk memiliki kekuatan spiritual keagamaan, pengendalian diri, kepribadian, dan kecerdasan.

Kemudian, dalam pasal 37, disebutkan bahwa pendidikan di Indonesia mewajibkan setiap sekolah dasar dan sekolah menengah harus memuat pendidikan matematika. Setiap sekolah harus memberikan pendidikan matematika sebagai bagian dari kurikulum di sekolah. Matematika adalah salah satu cabang ilmu pengetahuan yang sangat dibutuhkan karena keragaman manfaatnya sebagai alat bantu dalam kehidupan manusia. Menurut Adams dan Hamm, terdapat empat macam pandangan tentang posisi dan peran matematika yaitu sebagai suatu cara untuk berpikir, matematika sebagai suatu pemahaman tentang pola dan hubungan (pattern and relationship), matematika sebagai suatu alat (mathematics as a too), dan matematika sebagai bahasa atau alat untuk berkomunikasi (Wijaya, 2012).

Matematika merupakan salah satu mata pelajaran yang wajib diberikan pada setiap jenjang pendidikan. Menurut Naifatul dkk, keberhasilan proses pembelajaran matematika sangat berpengaruh dengan kemampuan koneksi matematis siswa, karena dengan meningkatkan kemampuan koneksi matematis siswa dapat memandang matematika sebagai suatu kesatuan yang dapat dipelajari dengan mudah secara berkelanjutan dari materi sebelumnya menuju materi selanjutnya, dan siswa mampu melihat kebermanfaatan ilmu matematika dalam menyelesaikan permasalahan yang ditemui dalam kehidupan sehari-hari. (Naifatul, dkk, 2019: 219-232). Menurut NCTM tujuan pembelajaran matematika yaitu untuk berkomunikasi (mathematical communication), belajar untuk bernalar (mathematical reasoning), belajar untuk memecahkan masalah (mathematical problem solving), belajar untuk mengaitkan ide (mathematical connection), dan belajar untuk merepresentasikan ide-ide (mathematical representation). Hal tersebut menunjukkan bahwa kemampuan komunikasi matematis perlu dimiliki dan dikembangkan oleh siswa untuk mencapai tujuan pembelajaran matematika.

National Council of Teacher of Mathematics (NCTM) (dalam Arifin, 2017) menyatakan bahwa tujuan pembelajaran matematika yaitu untuk berkomunikasi (mathematical communication), belajar untuk bernalar (mathematical reasoning), belajar untuk memecahkan masalah (mathematical problem solving), belajar untuk mengaitkan ide (mathematical connection), dan belajar untuk merepresentasikan ide-ide (mathematical representation). Salah satu kemampuan matematis yang perlu dimiliki dan dikembangkan siswa sejak dini adalah komunikasi matematis.

Komunikasi matematis merupakan salah satu bagian penting dalam pembelajaran matematika. Sebagaimana tertuang dalam NCTM (2000), komunikasi adalah bagian yang esensial dari matematika dan pendidikan matematika. Komunikasi matematis adalah cara peserta didik untuk berbagi ide matematika yang telah dipelajari dan diklarifikasi dalam pemahaman. Siswa yang mempunyai kemampuan komunikasi matematis yang baik dapat mempermudah 
siswa membuat berbagai representasi dalam menentukan penyelesaian masalah dalam kehidupan sehari-hari.

Berdasarkan hasil penelitian tiga tahunan Program for International Student Assessment (PISA) pada tahun 2015 didapatkan bahwa Indonesia menduduki peringkat 62 dari 72 negara yang ikut serta. Dari hasil penelitian PISA tersebut, diketahui bahwa Indonesia mengalami peningkatan hasil skor rata-rata kompetensi matematika dari 375 di tahun 2012 menjadi 386 di tahun 2015. Indonesia mengalami kenaikan yang signifikan yaitu 22,1, namun masih rendah jika dibandingkan dengan rata-rata Organization for Economic Cooperation and Development (OECD).

Hasil penelitian yang dilakukan Trends International Mathematics and Science Study (TIMSS) pada tahun 2015 menunjukkan bahwa komunikasi matematis Indonesia masih tergolong rendah, khususnya dalam materi geometri yang mendapatkan persentasi $28 \%$ dari $50 \%$ presentasi internasional. Indonesia menempati peringkat 45 dari 50 negara yang ikut serta. Hasil persentasi 28\% menunjukkan bahwa siswa Indonesia berada pada kemampuan matematika level dasar. Artinya siswa hanya mampu memecahkan permasalahan untuk masalah matematika yang sangat sederhana, kurang bisa mengkomunikasikan dan hanya mampu menjawab soal-soal yang biasa diajarkan dalam konteks permasalahan atau soal rutin.

Peneliti melakukan wawancara dan studi pendahuluan di SD Negeri Jampang 03 kelas $\mathrm{V}$ dengan memberikan soal yang berkaitan dengan kemampuan komunikasi matematis, tujuannya adalah untuk mengetahui mereka. Hal ini bertujuan untuk mengetahui kemampuan komunikasi matematis yang dimiliki siswa. Hasil studi pendahuluan menunjukkan bahwa kemampuan komunikasi matematis siswa masih tergolong rendah. Hal tersebut diperkuat dengan nilai rata-rata kemampuan komunikasi matematis sebesar 55,17. Dari 29 siswa, hanya 10 siswa atau 34\% yang mencapai KKM, sedangkan 19 siswa atau 66\% tidak mencapai KKM yang telah ditentukan yaitu 75. Siswa tidak terbiasa mengerjakan soal-soal yang membutuhkan kemampuan komunikasi metamatis. Hal ini terlihat dari siswa kurang mampu memahami soal, sehingga mengalami kesulitan dalam menyatakan ide-ide ke dalam bentuk matematis dan pada akhirnya siswa tidak mampu menentukan konsep yang harus digunakan untuk menyelesaikan permasalahan, siswa kebingungan ketika membaca data yang tersaji dalam bentuk gambar atau simbol matematika lainnya.

Salah satu model pembelajaran yang dapat meningkatkan kemampuan komunikasi matematis siswa adalah model permainan dalam pembelajaran. Permainan merupakan salah satu hal yang disukai anak-anak usia sekolah dasar. Bermain merupakan kebutuhan yang harus dipenuhi. Dengan bermain, anak merasa bahagia dan dapat dengan bebas mengekspresikan apa yang sedang dirasakan. Permainan ialah suatu alat untuk mengeksplorasi dunia anak, dari yang tidak diketahui hingga ia mengetahuinya. Menurut Andi, Keberadaan permainan telah diakui memiliki kontribusi yang positif bagi dunia pendidikan anak (Andi, 2018: 1-28). Terkadang belajar menjadi hal yang membosankan bagi anak karena belajar tidak semenarik permainan. Permainan tersebut bertujuan untuk memberikan pengalaman langsung dengan masuk ke situasi nyata dan memvisualisasikan benda-benda abstrak menjadi konkret. Oleh sebab itu, dibutuhkan pendidik yang kreatif dalam mengemas suatu pembelajaran, khususnya matematika. Pembelajaran matematika tidak selalu terfokus pada penjelasan guru di kelas dengan menggunakan papan tulis. Dengan demikian, penulis mencoba menggunakan suatu model 
pembelajaran yang berbasis permainan yang joyfully bagi siswa yang dinamakan "Finding My Secret Word'.

Model permainan dalam pembelajaran memiliki beberapa kelebihan yaitu dapat meningkatkan keaktifan siswa, aktivitas yang dilakukan siswa tidak hanya fisik, tetapi juga mental, dapat membangkitkan minat dalam pembelajaran, materi lebih mengesankan sehingga sukar dilupakan, memupuk rasa solidaritas dan kerjasama (Suprijono, 2009). Menurut Sadiman (dalam Maspalah, 2013) model permainan dalam pembelajaran mempunyai kelebihan yaitu adanya partisipasi aktif dari siswa untuk belajar, menyenangkan untuk dilakukan dan memberikan umpan balik langsung dan lain-lain.

Finding my secret word adalah permainan kelompok dengan menyiapkan soal sebanyak mungkin disertai jawaban, lalu perwakilan siswa menuliskan soal disertai poin yang telah mereka buat untuk disimpan di tempat yang ditentukan. Setiap kelompok harus mencari soal yang sudah disembunyikan sebanyak mungkin dan tidak boleh berpindah sebelum menyelesaikan soal yang ia peroleh, kelompok yang membuat soal mengoreksi jawaban kelompok lain dan memberitahukan jawaban yang benar (Nariswari dan Kurniasih, 2014). Adapun Indikator komunikasi matematis yang diungkapkan NCTM (2000) diantaranya adalah: 1) Menjelaskan ide matematika baik secara tulisan maupun lisan dan mendemonstrasikan serta menggambarnya secara visual, 2) Memahami ide matematika secara tulisan maupun lisan, dan 3) Menggunakan istilah, notasi matematika dan struktur-strukturnya dalam menyajikan suatu ide, menggambarkan hubungan dan model situasi.

Langkah-langkah permainan finding my secret word yang digunakan dalam penelitian ini, yaitu: Menjelaskan materi pembelajaran dengan media yang disediakan, Membagi siswa menjadi kelompok secara heterogen, Diskusi kelompok dalam menyiapkan 3 pertanyaan, Menempelkan soal tersebut di tempat yang tersembunyi, Mencari pertanyaan yang sudah disembunyikan oleh kelompok lain dan segera menyelesaikannya dalam waktu yang telah ditentukan, Perwakilan kelompok mencocokkan jawaban dengan kelompok lain dan memberi skor. Kelompok yang mendapatkan skor tertinggi menjadi pemenangnya.

Hal ini sesuai dengan penelitian Rhizki Dewi Queen (2014). Hasil penelitiannya menyatakan bahwa strategi bermain jawaban berbantu finding my secret word dapat meningkatkan keaktifan belajar dan kemampuan pemecahan masalah matematika dari siswa pasif dalam pembelajaran dan rata-rata mengerjakan soal tidak benar sehingga siswa menjadi aktif dan mampu mengerjakan soal dengan benar.

Berdasarkan uraian di atas, penulis tertarik melalukan penelitian yang dikhususkan untuk melihat kemampuan komunikasi matematis siswa melalui model permainan finding my secret word. Adapun judul yang penulis rangkai dalam penelitian ini adalah "Pengaruh Model Permainan Finding My Secret Word terhadap Kemampuan Komunikasi Matematis Siswa”.

\section{METODE}

Metode yang digunakan dalam penelitian ini adalah metode kuasi eksperimen (quasi experimental) dengan desain The Nonequivalent Posttest-Only Group Design. Penelitian ini dilakukan untuk menguji pengaruh model permainan finding my secret word terhadap komunikasi matematis 
siswa. Populasi dalam penelitian ini adalah seluruh siswa SD Negeri Jampang 03 dengan sampel yang diambil sebanyak dua kelas yaitu kelas V-A sebagai kelas kontrol dengan jumlah 29 siswa dan kelas V-B sebagai kelas eksperimen dengan jumlah 29 siswa. Pada kelas ekperimen pembelajaran matematika menggunakan permainan finding my secret word. sedangkan pada kelas kontrol pembelajaran matematika menggunakan metode konvensional. Materi yang diajarkan pada kedua kelas tersebut adalah bangun ruang.

Instrumen yang digunakan untuk mengumpulkan data dalam penelitian ini yaitu tes kemampuan komunikasi matematis, wawancara, dan observasi. Adapun data kuantitatif yang berhasil dikumpulkan dianalisis menggunakan program SPSS 22.0. Teknik analisis data penelitian ini adalah uji normalitas, uji homogenitas, dan uji hipotesis.

\section{HASIL PENELITIAN DAN PEMBAHASAN}

Data hasil posttest kemampuan komunikasi matematis siswa kelas eksperimen dan kelas kontrol dengan menggunakan software SPSS 22,0 dapat dilihat pada tabel sebagai berikut:

Tabel 1. Deskripsi Data Posttest Kelas Eksperimen dan Kelas Kontrol

\begin{tabular}{lrr}
\hline & Kelas Eksperimen & Kelas Kontrol \\
\hline M Valid & 29 & 29 \\
Mean & 0 & 0 \\
Std. Error of & 71.34 & 58.17 \\
Mean & 2.932 & 3.426 \\
Median & 75.00 & 63.00 \\
Mode & 79 & 58 \\
Std. Deviation & 15.789 & 18.447 \\
Variance & 249.305 & 340.291 \\
Range & 63 & 59 \\
Minimum & 33 & 29 \\
Maximum & 96 & 88 \\
Sum & 2069 & 1687 \\
\hline
\end{tabular}

Berdasarkan tabel di atas, dapat diketahui bahwa hasil posttest kelas eksperimen diperoleh data sebanyak 29 siswa dengan nilai rata-rata (mean) sebesar 71,34, nilai tengah (median) sebesar 75,00, nilai yang sering muncul (mode) sebesar 79, standar deviasi sebesar 15,789, variansi sebesar 249,305, range sebesar 63, nilai terendah (minimum) sebesar 33 dan nilai tertinggi (maximum) sebesar 96. 
Sedangkan hasil posttest kelas kontrol diperoleh data sebanyak 29 siswa dengan nilai ratarata (mean) sebesar 58,17, nilai tengah (median) sebesar 63,00, nilai yang sering muncul (mode) sebesar 58, standat deviasi sebesar 18,447, variansi sebesar 340,291, range sebesar 59, nilai terendah (minimum) sebesar 29 dan nilai tertinggi (maximum) sebesar 88.

Berdasarkan deskripsi data di atas terdapat perbedaan hasil posttest antara kelas eksperimen dan kelas kontrol, sebagai berikut:

Tabel 2. Perbandingan Hasil Posttest Kelas Eksperimen dan Kelas Kontrol

\begin{tabular}{ccc}
\hline Statistika & Eksperimen & Kelas \\
& 71,34 & Kontrol \\
\hline Rata-rata & 75 & 58,17 \\
Median & 79 & 63 \\
Modus & 249.305 & 58 \\
Varians & 15.789 & 340.291 \\
Standar Deviasi & 96 & 18.447 \\
Nilai Maksimum & 33 & 29 \\
Nilai Minimum & &
\end{tabular}

Berdasarkan tabel di atas, diketahui nilai rata-rata kelas eksperimen sebesar 71,34 dengan nilai tertinggi yaitu 96 dan nilai terendah 33. Sedangkan nilai rata-rata kelas kontrol sebesar 58,17 dengan nilai tertinggi 88 dan nilai terendah yaitu 29. Selisih nilai tertinggi kedua kelas tersebut adalah 8 dan selisih nilai terendah adalah 4 . Hal ini menunjukkan bahwa kelas eksperimen lebih tinggi daripada kelas kontrol dimana nilai tertinggi berada pada kelas eksperimen dan nilai terendah berada pada kelas kontrol.

Nilai median dan modus kelas eksperimen sebesar 75 dan 79. Sedangkan nilai median dan modus kelas kontrol sebesar 63 dan 58. Artinya jumlah siswa kelas eksperimen lebih banyak mendapatkan nilai di atas KKM yaitu 75. Terdapat pula perbedaan pada nilai varians. Kelas eksperimen memperoleh nilai varians sebesar 249.305 sedangkan kelas kontrol memperoleh nilai varians sebesar 340.291. Hal ini menunjukkan bahwa kelas kontrol memiliki penyebaran nilai yang lebih bervariasi sedangkan kelas eksperimen hanya mengelompok pada nilai di atas rata-rata. Nilai standar deviasi kelas eksperimen sebesar 15.789 sedangkan nilai standar deviasi kelas kontrol sebesar 18.447. Dari data tersebut diketahui nilai standar deviasi kelas eksperimen lebih kecil dibandingkan kelas kontrol. Artinya bahwa sebaran data kelas eksperimen lebih mendekati nilai rata-rata sedangkan sebaran data kelas kontrol menjauhi dari nilai rata-rata.

Penelitian ini menggunakan 2 indikator komunikasi matematis, yaitu written text dan mathematical expression. Dimana, terdapat perbandingan nilai posttest pada masing-masing indikator pada kelas eksperimen dan kelas kontrol, sebagai berikut: 
Tabe1 3. Perbandingan Hasil Posttest Kelas Eksperimen dan Kelas Berdasarkan Indikator

\begin{tabular}{cccc}
\hline No & Indikator & Kelas Eksperimen & Kelas Kontrol \\
\hline 1 & Written Text & 65,7 & 57,4 \\
2 & Mathematical Expression & 76,7 & 58,8 \\
\hline
\end{tabular}

Berdasarkan tabel di atas, diketahui kelas eksperimen memperoleh nilai rata-rata indikator pertama yaitu written text sebesar 65,7, Sedangkan kelas kontrol memperoleh nilai rata-rata indikator written text sebesar 57,4. Hal ini menunjukkan bahwa pada indikator written text kelas eksperimen lebih tinggi daripada kelas kontrol. Pada indikator kedua yaitu mathematical expression, nilai rata-rata kelas eksperimen lebih tinggi yaitu 76,7 dibandingkan kelas kontrol yaitu 58,8.

Selisih persentase tersebut dikarenakan banyaknya tahapan atau langkah-langkah pembelajaran pada kelas eksperimen yang menggunakan model permainan finding my secret word. Siswa terbiasa membuat soal dari situasi yang telah diberikan, sehingga mereka lebih mudah menyatakan ide atau gagasan dalam model matematika. Siswa diberikan pengalaman langsung dalam berbagai masalah dengan tujuan dapat menggunakan konsep yang dipelajari dalam menyatakan ide matematika. Secara visual, perbandingan persentasi hasil posttest kelas eksperimen dan kelas kontrol berdasarkan indikator, sebagai berikut:

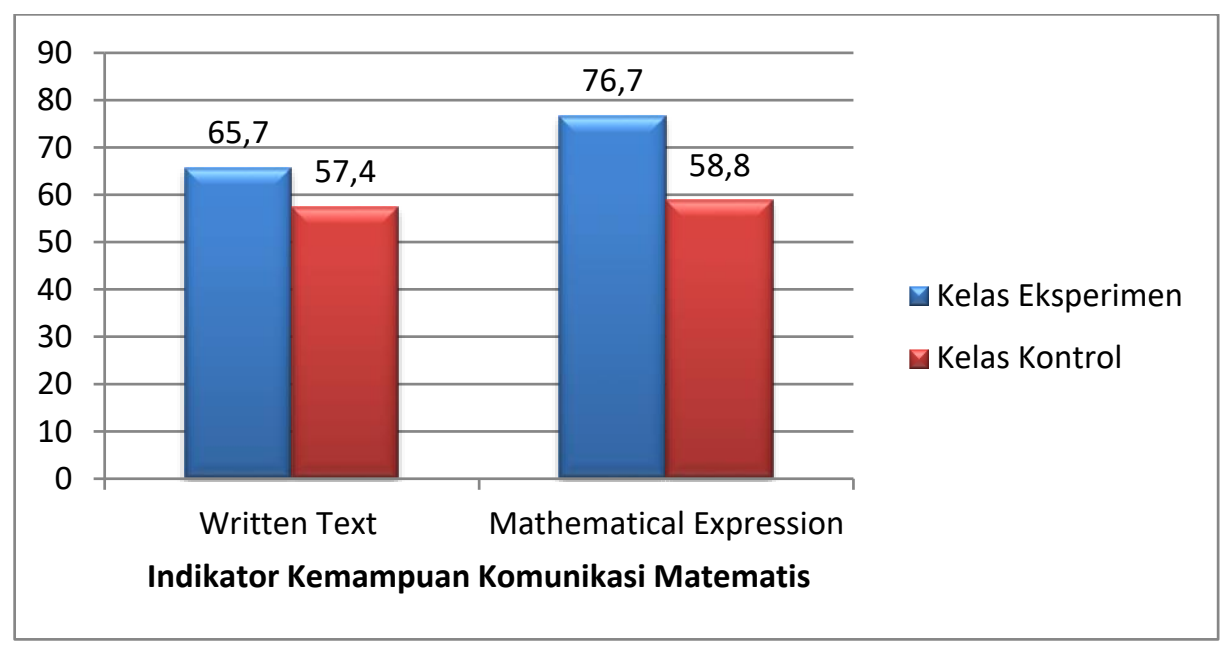

Gambar 1. Diagram Batang Persentase Hasil Posttest Kelas Eksperimen dan Kelas Kontrol

Berdasarkan gambar di atas, diketahui bahwa kemampuan komunikasi matematis siswa kelas eksperimen yang menggunakan model permainan finding my secret word lebih tinggi daripada kelas kontrol yang menggunakan pembelajaran konvensional.baik secara keseluruhan statistic maupun per indikator. 
Uji normalitas yang digunakan dalam penelitian ini menggunakan software SPSS 22.0 dengan metode Kolmogorov-Smirnov. Suatu data dikatakan berdistribusi normal jika nilai signifikansi probabilitas $>0,05$.

Tabel 4. Hasil Uji Normalitas Posttest Kelas Eksperimen dan Kelas Kontrol

\begin{tabular}{|c|c|c|c|}
\hline & \multicolumn{3}{|c|}{ Kolmogorov-Smirnova } \\
\hline & Statistic & df & Sig. \\
\hline kelas_eksperimen & .134 & 29 & .193 \\
\hline kelas_kontrol & .155 & 29 & .075 \\
\hline
\end{tabular}

Berdasarkan tabel di atas, dapat disimpulkan bahwa hasil posttest pada kelas eksperimen memperoleh signifikansi 0,193. Sedangkan pada kelas kontrol memperoleh signifikansi 0,075. Hal ini menunjukkan bahwa data tersebut berdistribusi normal karena signifikansi kelas eksperimen yaitu $0,193>0,05$ dan signifikansi kelas kontrol 0,075 > 0,05.

Uji homogenitas dalam penelitian ini menggunakan uji One Way Anova pada software SPSS 22.0. Suatu data dikatakan homogen jika nilai signifikansi. > 0,05. Karena hasil yang didapat normal, maka dilakukan uji lanjutan yakni uji homogenitas.

Tabel 5. Hasil Uji Homogenitas Posttest Kelas Eksperimen dan Kelas Kontrol

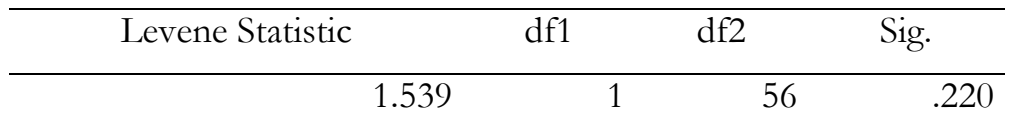

Berdasarkan tabel di atas, dapat diketahui bahwa hasil uji homogenitas dari posttest kelas eksperimen dan kontrol memperoleh signifikansi 0,220. Hal ini menunjukkan bahwa 0,220 > 0,05, sehingga dapat dikatakan bahwa siswa kelas eksperimen dan kelas kontrol berasal dari populasi yang mempunyai varians yang sama atau homogen.

Uji hipotesis dengan analisis Independent Sample T-Test menggunakan software SPSS 22,0. Kriteria pengujian hipotesis adalah jika nilai signifikansi t-test $<0,05$ maka $\mathrm{H}_{0}$ ditolak dan $\mathrm{H}_{1}$ diterima dan jika nilai signifikansi t-test $>0,05$ maka $\mathrm{H}_{0}$ diterima dan $\mathrm{H}_{1}$ ditolak.

Tabel 6. Hasil Uji-t Posttest Kelas Eksperimen dan Kelas Kontrol

\begin{tabular}{llrrr}
\hline & & \multicolumn{3}{c}{ t-test for Equality of Means } \\
\cline { 3 - 5 } & & \multicolumn{3}{c}{} \\
& Sig. & Mean & Std. Error \\
& & $(2-$-tailed $)$ & Difference & Difference \\
\hline hasil & Equal variances assumed & .005 & 13.172 & 4.509 \\
posttest & Equal variances not assumed & .005 & 13.172 & 4.509 \\
\hline
\end{tabular}


Berdasarkan tabel di atas, dapat diketahui bahwa hasil uji-t posttest kelas ekperimen dan kelas kontrol memperoleh signifikansi (2-tailed) 0,005. Hal ini menunjukkan bahwa 0,005<0,05, sehingga dapat disimpulkan $\mathrm{H}_{0}$ ditolak dan $\mathrm{H}_{1}$ diterima. Artinya rata-rata kemampuan komunikasi matematis siswa kelas eksperimen lebih tinggi daripada rata-rata kemampuan komunikasi matematis siswa kelas kontrol.

Berdasarkan penelitian yang telah dilakukan, peneliti menemukan pengaruh yang signifikan pada penggunaan model permainan finding my secret word terhadap kemampaun komunikasi matematis siswa di kelas V SD Negeri Jamoang 03. Hal tersebut dibuktikan dengan nilai rata-rata kelas eksperimen lebih tinggi yaitu 71,34 daripada kelas kontrol yaitu 58,17.

Menurut John Peaget menyatakan bahwa kisaran usia 7 - 11 tahun disebut tahap operasi konkret. Pada tahap ini siswa bertindak dan berpikir mengenai fenomena konkret yang terdapat dikehidupan (Isrok'atun, 2018). Proses pembelajaran matematika dapat menggunakan bendabenda konkret atau diberikan suatu permasalahan yang terdapat dalam kehidupan sehari-hari. Konsep matematika yang masih abstrak membuat siswa kurang berminat dalam pembelajaran matematika. Konsep yang masih abstrak tersebut dapat dimanipulasi menjadi objek-objek yang konkret sehingga mudah dipahami siswa. Dengan demikian, siswa SD perlu menguasai matematika khususnya kemampuan komunikasi matematis melalui media ataupun model pembelajaran. Model pembelajaran yang berkembang dewasa ini telah diciptakan dengan tujuan mempermudah siswa dalam menyukai matematika salah satunya yaitu model permainan (Amril dan Ernawati, 2016).

Permainan matematika adalah suatu permainan yang mengandung objek atau unsur matematika, misalnya konsep dalam geometri, statistika dan sebagainya. Obyek yang digunakan dapat berupa titik, garis, bangun ruang, rumus-rumus dan sejenisnya (Syafik, 2012). Adapun tujuan dari permainan tersebut untuk menghilangkan keseriusan yang berlebih dalam belajar. Salah satu model permainan yang digunakan dalam proses pembelajaran matematika yaitu permainan finding my secret word

Keterampilan belajar siswa setelah dilakukan wawancara mengalami peningkatan dari tidak berani bertanya menjadi berani bertanya. Hasil penelitian tersebut menunjukkan bahwa permainan finding my secret word memberikan pengaruh yang berbeda terhadap pembelajaran matematika. Berikut suasana pembelaaran yang menggunakan permainan finding my secret word di kelas V SD Negeri Jampang 03: 

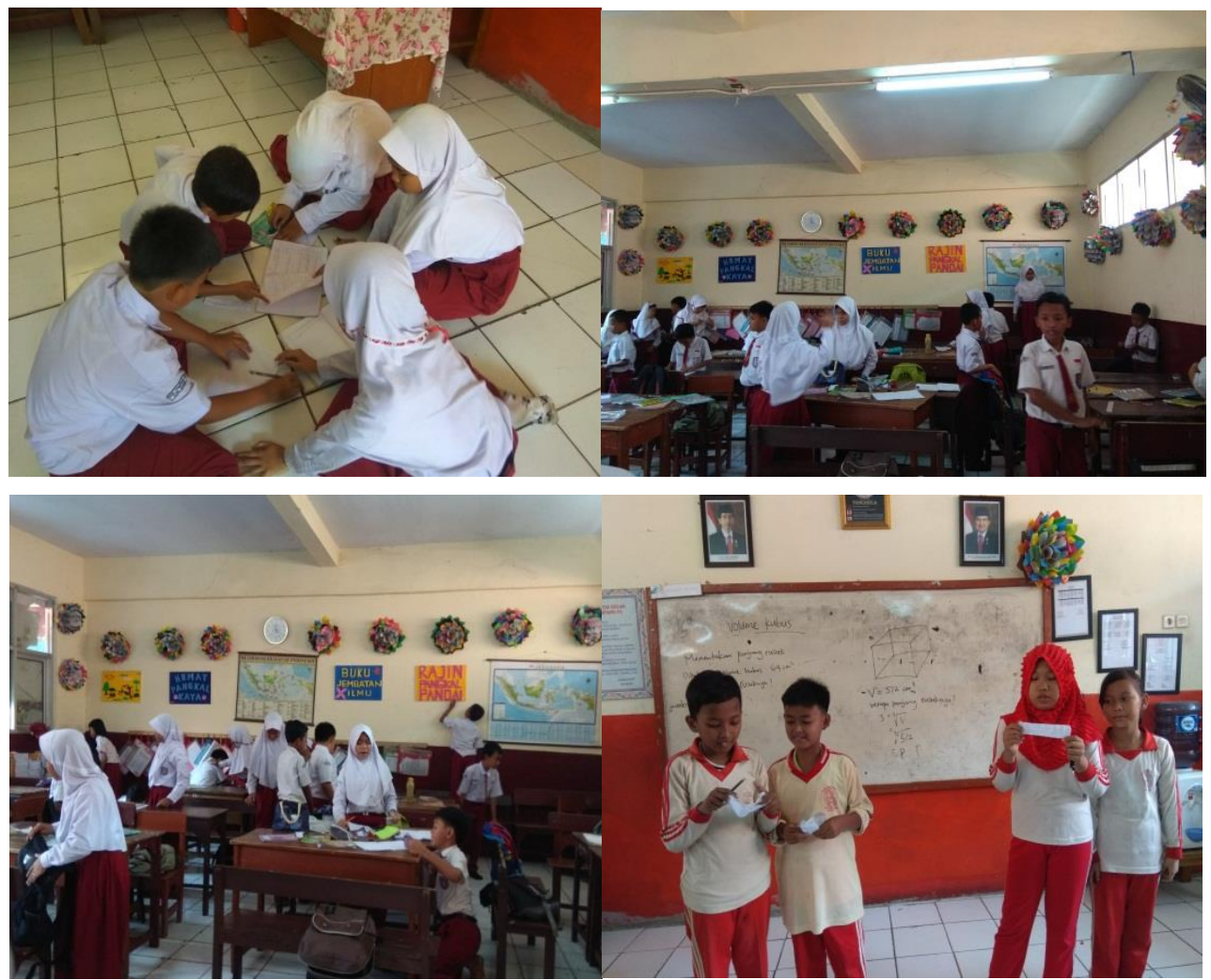

Gambar 2. Permainan Finding My Secret Word

Siswa dapat mengekspresikan ide-ide matematika dalam bentuk tulisan dan secara kelompok siswa mampu mengajukan soal berdasarkan kehidupan sehari-hari yang mereka temui. Lalu, guru memberikan Lembar Kerja Siswa (LKS) guna melatih kemampuan komunikasi matematis siswa. Berikut adalah soal-soal yang dibuat oleh salah satu kelompok yaitu:

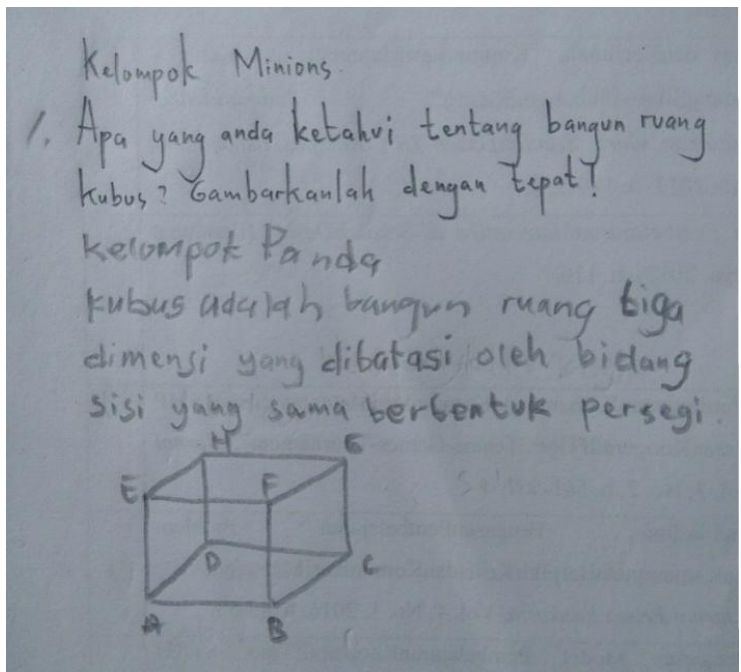

Gambar 3. Soal dan jawaban yang Dibuat Siswa 1 
Gambar di atas merupakan salah satu bentuk soal yang dibuat oleh salah satu kelompok dan telah diselesaikan oleh kelompok lain pada saat bermain finding my secret word. Siswa diperintahkan membuat soal sesuai dengan tujuan pembelajaran yaitu mengidentifikasi bangun ruang. Sebelum membuat soal, setiap kelompok melakukan diskusi terlebih dahulu dan harus mengetahui penyelesaian dari soal yang akan dibuatnya. pada pembelajaran kali ini semua kelompok dapat menyelesaikan tugas membuat soal dengan baik. Hal ini dapat terlihat dari soal yang dibuat oleh kelompok sesuai dengan tujuan pembelajaran yang ingin dicapai.

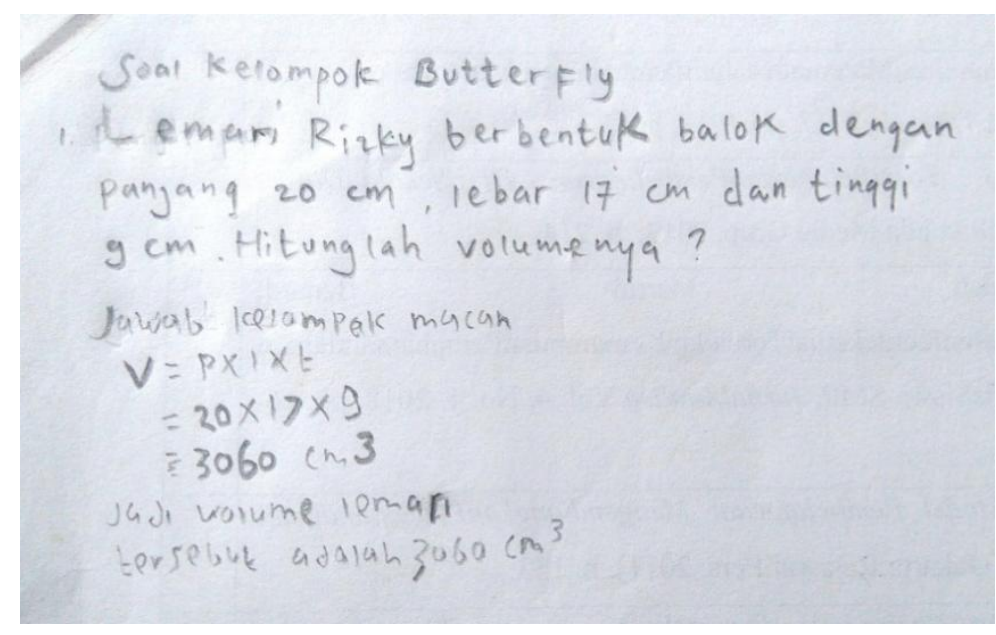

Gambar 4. Soal dan jawaban yang Dibuat Siswa 2

Gambar di atas merupakan salah satu bentuk soal yang dibuat oleh salah satu kelompok dan telah diselesaikan oleh kelompok lain pada saat bermain finding my secret word. Siswa diperintahkan membuat soal sesuai dengan tujuan pembelajaran yaitu menghitung volume bangun ruang. Sebelum membuat soal, setiap kelompok melakukan diskusi terlebih dahulu dan harus mengetahui penyelesaian dari soal yang akan dibuatnya. Pada pembelajaran kali ini semua kelompok dapat menyelesaikan tugas membuat soal dengan baik. Hal ini dapat terlihat dari soal yang dibuat oleh kelompok sesuai dengan tujuan pembelajaran yang ingin dicapai..

Permainan finding my secret word merangsang peningkatan kemampuan komunikasi matematis siswa, karena dalam membuat soal siswa perlu membaca suatu informasi yang diberikan dan mengomunikasikan pertanyaan secara tertulis. Selain itu, siswa terlibat dalam aktivitas yang terkait dengan pengajuan soal dan membantu siswa dalam mengembangkan keyakinan terhadap matematika, sebab ide-ide matematika siswa dicobakan untuk memahami masalah yang sedang dikerjakan.

Hasil penelitian menunjukkan bahwa dengan model permainan finding my secret word dalam pembelajaran matematika memudahkan siswa untuk memahami materi dan mengomunikasikan penyelesaian masalah dalam kehidupan sehari-hari dari situasi yang diberikan kepada siswa. Hal ini dapat dibuktikan dengan nilai rata-rata kelas eksperimen lebih besar yakni sebesar 71,34 dibandingkan kelas kontrol sebesar 58,17. Hasil analisis uji-t diperoleh nilai Sig. 0,005 < 0,05 yang menunjukkan bahwa model permainan finding my secret word memberi pengaruh positif terhadap kemampuan komunikasi matematis siswa. 
Siswa diberikan posttest yang terdiri dari 6 soal dalam bentuk uraian. Posttest ini bertujuan untuk mengukur kemampuan komunikasi matematis siswa kelas eksperimen dan kelas kontrol pada materi bangun ruang. Data hasil posttest menunjukkan bahwa adanya perbedaan yang cukup signifikan antara kedua kelas tersebut. Rata-rata kemampuan komunikasi matematis siswa kelas eksperimen sebesar 71,34 sedangkan kelas kontrol sebesar 58,17. Perbedaan lain yang dihasilkan dalam penelitian ini adalah rata-rata tiap indikator komunikasi matematis siswa. Hal ini terlihat dari rata-rata persentase indikator written text dan mathematical expression kelas eksperimen sebesar 65,7 dan 76,7. Sedangkan rata-rata persentase indikator written text dan mathematical expression kelas kontrol sebesar 57,4 dan 58,8. Selisih rata-rata kedua kelas tersebut dipengaruhi oleh hasil jawaban siswa terhadap soal posttest yang diberikan. Berikut ini disajikan analisis jawaban komunikasi matematis antara kelas eksperimen dan kelas kontrol berdasarkan indikator yang digunakan dalam penelitian ini, sebagai berikut:

Pertama, Pada indikator written text siswa diminta untuk menyelesaikan masalah dari situasi yang diberikan guru dalam bentuk gambar dan mampu menyampaikan ide-ide matematis melalui tulisan menggunakan bahasa sendiri. Dalam penelitian ini indikator tersebut terdapat pada nomor 2,4 dan 6. Berikut disajikan soal nomor 6 yang mewakili indikator written text.

\section{Soal posttest nomor 6}

Perhatikan gambar berikut! Fatinah mendapatkan paket boneka di dalam kardus berbentuk kubus. Ia ingin membuka kardus tersebut dengan memotong pada bagian rusuk-rusuknya sehingga akan menghasilkan sebuah jaring-jaring kubus. Jelaskan pengertian dari jaring-jaring dengan bahasamu! Gambarlab 2 jaring-jaring kubus yang anda ketabui!

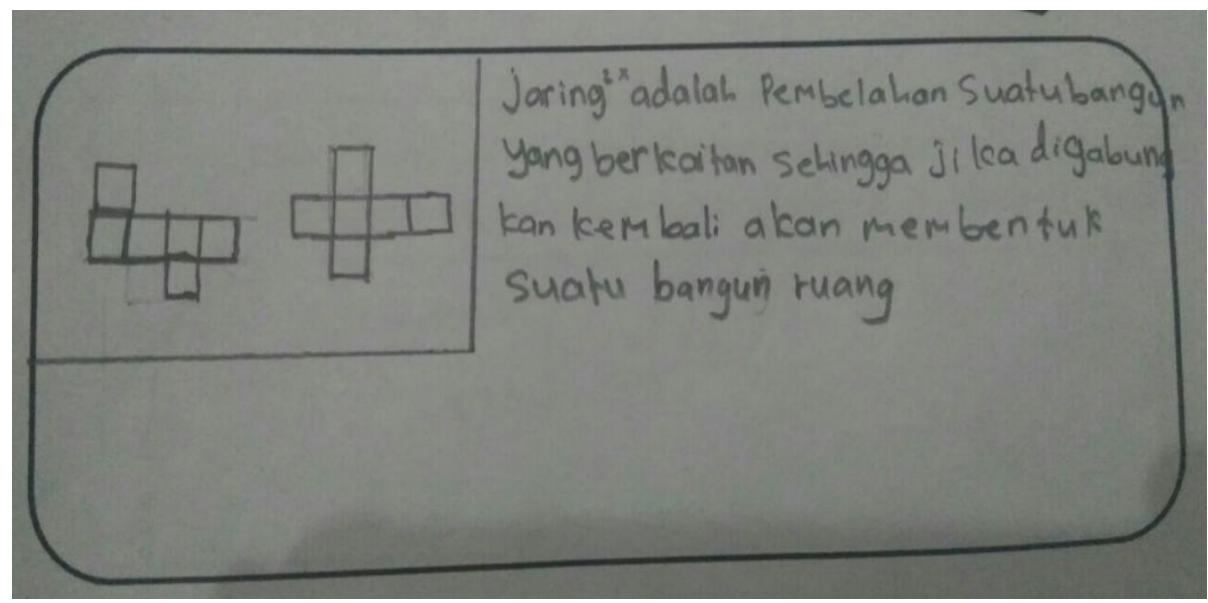

Gambar 5. Contoh Jawaban Soal Posttest Nomor 6 Kelas Eksperimen

Pada gambar di atas, menunjukkan bahwa siswa kelas eksperimen mampu menjelaskan pengertian jaring-jaring dengan bahasa sendiri secara logis dan menyajikannya dalam bentuk gambar jaring-jaring kubus. Artinya siswa telah mampu menentukan solusi dari situasi yang diberikan dan menyajikannya dalam bentuk gambar dan mampu menjabarkan ide-ide matematis dengan bahasa sendiri. 


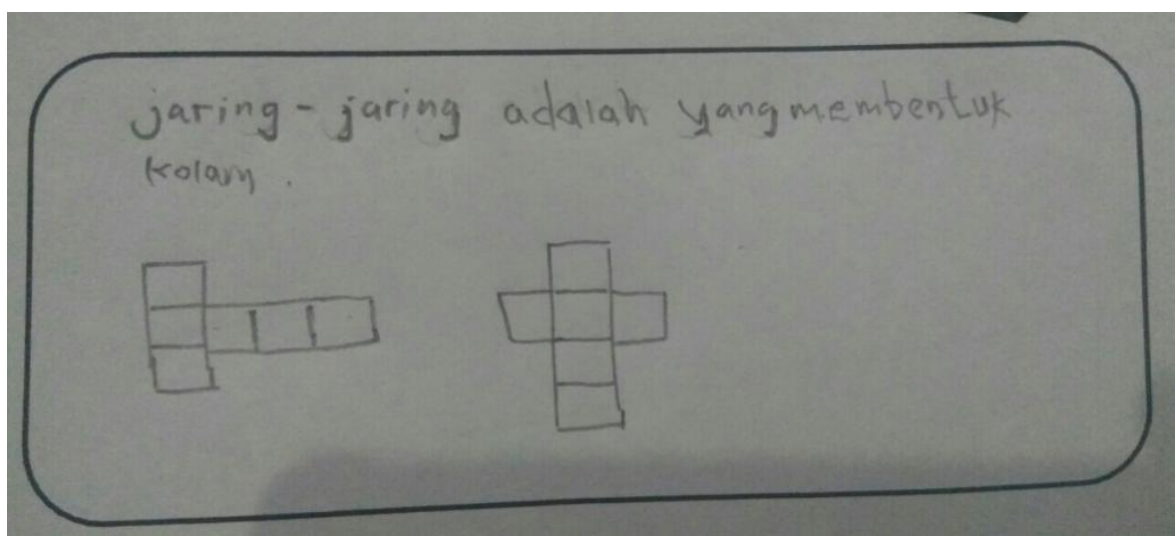

Gambar 6. Contoh Jawaban Soal Posttest Nomor 6 Kelas Kontrol

Pada gambar di atas, menunjukkan bahwa siswa kelas kontrol belum mampu menjelaskan pengertian jaring-jaring dengan benar, tetapi siswa mampu mengambarkannya dengan tepat. Artinya siswa hanya mampu menyampaikan atau mengekspresikan di antara beberapa ide matematika.

Siswa kelas eksperimen dan kelas kontrol menggunakan konsep penyelesaian yang sama dan menyajikan gambar bangun ruang. Namun, pada kelas kontrol terdapat kesalahan dalam menyampaikan atau menjelaskan ide-ide matematis, sedangkan kelas ekpserimen penjelasannya lebih lengkap dan tepat. Maka, dapat disimpulkan bahwa kedua kelas sudah mampu menjelaskan dan menghubungkan situasi atau ide matematika dalam bentuk gambar bangun ruang dan sebaliknya. Hal tersebut menunjukkan bahwa permainan finding my secret word melatih siswa untuk membuat atau mengkonstruksi soal sehingga memudahkan dalam mengekspresikan ide-ide matematis. Soal-soal yang dimunculkan seringkali memicu terbentuknya pemahaman yang lebih mantap saat mengerjakan soal posttest.

Kedua, Pada indikator mathematical expression siswa diminta untuk menjabarkan situasi matematika dari peristiwa sehari-hari dalam bentuk konsep atau model matematika. Dalam penelitian ini indikator tersebut terdapat pada nomor 1, 3 dan 5. Berikut disajikan soal nomor 6 yang mewakili indikator mathematical expression.

\section{Soal posttest nomor 5}

Sebuah kolam ikan milik pak. Anton berbentuk balok dengan volume $315 \mathrm{~cm}^{3}$, lebar $7 \mathrm{~cm}$ dan tinggi $5 \mathrm{~cm}$. Buatlah model matematika untuk menghitung panjang kolam ikan Pak Anton! 


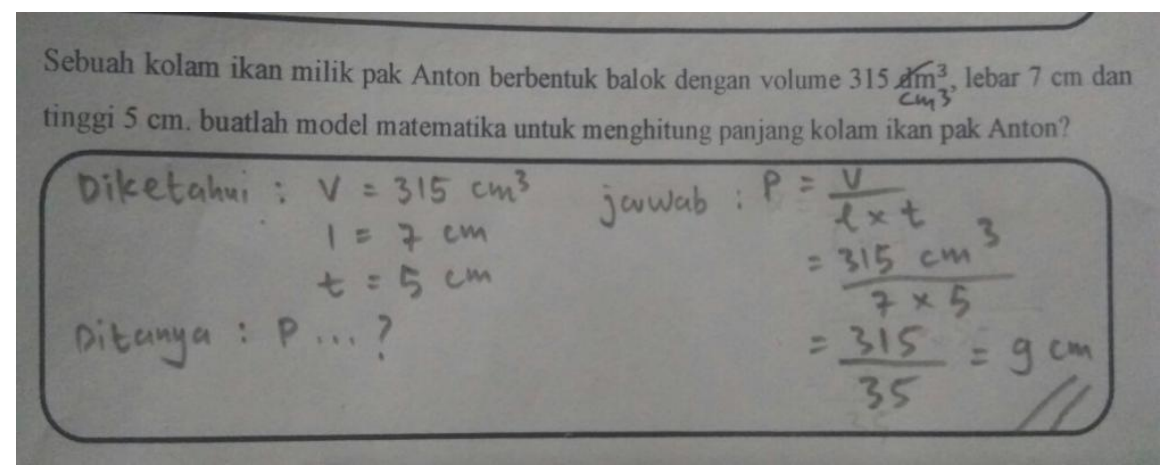

Gambar 7. Contoh Jawaban Soal Posttest Nomor 5 Kelas Eksperimen

Pada gambar di atas, menunjukkan bahwa siswa kelas eksperimen mampu menyelesaikan permasalahan dari situasi yang diberikan guru. Siswa terlebih dahulu menuliskan informasi dari data yang diketahui. Siswa mampu menghitung panjang balok dengan benar dan menuliskan rumusnya secara tepat. Artinya siswa mampu membuat model matematika dari peristiwa sehari-hari dalam konsep bangun ruang.

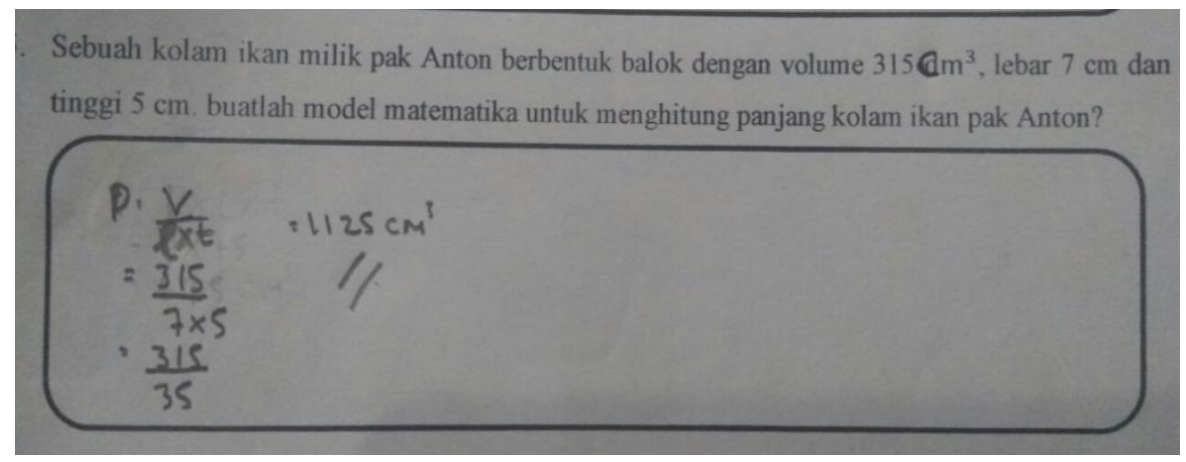

Gambar 8. Contoh Jawaban Soal Posttest Nomor 5 Kelas Kontrol

Pada gambar di atas, menunjukkan bahwa siswa belum mampu menghitung panjang balok. Siswa kelas kontrol tidak menuliskan data informasi yang diketahui. Namun, siswa sudah mampu membuat model matematika dari peristiwa sehari-hari dalam konsep bangun ruang dengan menuliskan rumus secara tepat.

Siswa kelas eksperimen dan kelas kontrol menggunakan konsep penyelesaian yang sama, namun pada kelas kontrol terdapat kesalahan dalam perhitungan, sedangkan kelas eksperimen lebih rinci dan tepat. Maka, dapat disimpulkan bahwa kedua kelas sudah mampu menyatakan peristiwa sehari-hari dalam konsep matematika mengenai bangun ruang. Namun terdapat beberapa siswa kelas kontrol yang belum mampu menyelesaikan permasalahannya secara tepat. Hal ini menunjukkan bahwa model permainan finding my secret word melatih siswa untuk membuat atau mengkonstruksi soal sehingga memudahkan dalam menyampaikan ide-ide matematis. Soal-soal yang dimunculkan seringkali memicu terbentuknya pemahaman yang lebih mantap saat mengerjakan soal posttest. 


\section{KESIMPULAN}

Berdasarkan hasil penelitian yang telah dilaksanakan oleh peneliti pada materi bangun ruang memperoleh kesimpulan bahwa model permainan finding my secret word berpengaruh terhadap kemampuan komunikasi matematis siswa. Hal ini dibuktikan dengan hasil hipotesis yang menunjukkan nilai t sebesar 0,005 dengan taraf signifikansi 0,05 . Serta nilai rata-rata posttest kelas eksperimen lebih tinggi dibandingkan kelas kontrol yaitu 71,34 untuk kelas eksperimen dan 58,17 untuk kelas kontrol. Adanya perbedaan tersebut karena kontribusi dari perlakuan yang berbeda selama penelitian. Dimana kelas eksperimen menggunakan model permainan finding my secret word disedangkan kelas kontrol menggunakan metode konvensional.

\section{DAFTAR PUSTAKA}

Amril dan Ernawati. Pengaruh Metode Permainan Terhadap Hasil Belajar Perkalian Pada Mata Pelajaran Matematika kelas III SDN 319 Lokajaha Kabupaten Bulukumba. Jurnal Kajian Pendidikan Dasar: FKIP Universitas Muhammadiyah Makassar. Vol. 1. No. 2, 2018.

Arifin, Fatkhul dan Tatang Herman. The Influence of E-Learning Model Web Enhanced Course To Conceptual Understanding and Self Regulated Learning in Mathematics for Elementary School Students. TARBIYA: Journal of Education in Muslim Society. Vol. 4. No. 1. 2017.

Depdiknas. Undang-Undang Republik Indonesia No. 20 Tabun 2003 tentang Sistem Pendidikan Nasional 2003.

Djamarah, Syaiful Bahri dan Aswan Zain. Strategi Belajar Mengajar. Jakarta: Rineka Cipta, 2015.

Hodiyanto, Kemampuan Komunikasi Matematis dalam Pembelajaran Matematika, AdMathEdu, Vol. 7, No. 1, 2017,

Isrok'atun dan Amelia Rosmala. Model-Model Pembelajaran Matematika. Jakarta: PT. Bumi Aksara. 2018.

Kusuma, Ade Irma dan Santi Irawati. Pengembangan Media Pembelajaran Melalui Permainan "Hunting Treasure" Pada Materi Himpunan untuk Siswa Kelas Bilingual VII-A di SMP Negeri 16 Malang. Jurnal Pendidikan Matematika Universitas Negeri Malang. Vol. 1. No. 2. 2013.

Musyarofah, N., Arifin, F., \& Firdaus, F. M. (2019). PENGGUNAAN MEDIA KOMIK UNTUK MENINGKATKAN KEMAMPUAN KONEKSI MATEMATIS SISWA SEKOLAH DASAR. JMIE (Journal of Madrasah Ibtidaiyah Education), 3(2), 219-232

Nariswari, Rhizki Dewi Queen dan Nila Kurniasih, Peningkatan Keaktifan, Pemecahan Masalah dan Keterampilan Belajar Matematika Menggunakan Strategi Bermain Jawaban Berbantu Finding My Secret Word. Ekuivalen Jurnal Pendidikan Matematika. Vol. 18. No. 3. 2014. 
National Council of Teacher of Mathematics (NCTM). Principles and Standards for School Mathematics. Reston Virginia: NCTM. 2000.

Pane, Nursyahbani Sitorus, dkk. Analisis Kemampuan Komunikasi Matematis Siswa Pada Materi Penyajian .Data Di Kelas VII MTs Islamyiah Medan. AXIOM. Vol. 7.No. 2, 2018.

Prastowo, A. (2018). Permainan tradisional Jawa sebagai strategi pembelajaran berbasis kearifan lokal untuk menumbuhkan keterampilan global di MI/SD. JMIE (Journal of Madrasah Ibtidaiyah Education), 2(1), 1-28.

Rusman. Model-Model Pembelajaran: Mengembangkan Profesionalisme Guru. Jakarta:Rajawali Pers. 2011.

Sastriawati, Gusni, Pembelajaran dengan Pendekatan Open Ended untuk Meningkatkan Pemahaman dan Kemampuan Komunikasi Matematis Siswa SMP. ALGORITMA. Vol. 1. No. 1. 2006.

Suprijono, Agus. Cooperative Learning. Yogyakarta: Pustaka Pelajar. 2009.

Susanto, Ahamd. Toeri Belajar dan Pembelajaran Di Sekolah Dasar. Jakarta: Kencana Prenada Media Grup. 2013.

Syafik, Abu. Permainan Matematika Sebagai Metode Alternatif dalam Pembelajaran Matematika Pada Siswa kelas 1 SD. Jurnal LIMIT-Pendidikan Matematika. Vol. 1. No. 2. 2012.

Tiffany, Febry ddk., Analysis Mathematical Communication Skills Student at the Grade IX Junior High School. International Journal Of Advance research and Innovative Ideas in Education. Vol. 3. No. 2. 2017.

Wijaya, Ariyadi. Pendidikan Matematika Realistik. Yogyakarta: Graha Ilmu. 2012.

Zulaihah, Anita dan Asih mardati. Optimalisasi Active Learning dan Character Bulding dalam Meningkatkan Daya Saing Bangsa di Era MEA. Prosiding Seminar Nasional. 2016. 